\title{
From Confrontation to Collaboration: Peasant Negotiations in the Arena of Decentralization
}

\section{Amin Tohari}

\begin{abstract}
Decentralization and local democracy are two inseparable elements of post-New Order Indonesia development politics. Furthermore, the quality of decentralization to a certain extent is influenced by the depth and quality of local democratic practices. This study reveals that decentralization is not only an arena of competition between local elites in possession of capital through local democratic institutions, but also an arena in which grassroots groups or peasants could fight for their land rights. This study observes that local democratic procedures and institutions that are practiced in unison with decentralization are not utilized by the lower classes in the struggle for their rights. This shows the failure of local democratic institutions from taking root in the marginal groups. The success of peasant movements in the struggle for their rights and the practice of local elite domination of the decentralization arena does not come out of the blue, but is related to the history of the formation of the agrarian structure and social class. This study concludes that on one side, local elites trust democratic institutions and procedures to achieve their goals, while on the other side the grassroots have their own logic on how local democracy should have been practiced, namely by not separating practice of local democracy from the missions of justice and social welfare for the common good.
\end{abstract}

\section{Keywords}

Decentralization; local democracy; agrarian structure; social class structure; local elites; peasants

\section{Introduction}

This article will look at how peasants marginalized by the unfair agrarian structure make use of political arenas to negotiate their interests in the context of decentralization. The effectiveness of decentralization as a form of governance that is agreed upon to operate at the local level is strongly associated not only to the depth of local democracy and local power configuration, but is also determined by the basic structure of the main livelihood of society members that shape

Amin Tohari is the founder of the SatuKata Research School. He completed his $\mathrm{PhD}$ in The Department of Politics and Governance, Universitas Gadjah Mada, Indonesia.

\section{Corresponding Author:}

Amin Tohari, the SatuKata Research School, Indonesia.

Email: amintohari@mail.ugm.ac.id 
the configuration of social classes (Sorj and Hutton 1980; Midlarsky 1992). Deepening democracy requires at least two major elements: citizenship awareness that grows and is strengthened, and collective social actors and civil society that actualize themselves. The first can be seen from whether the number of people participating regularly and directly in public decision-making is increasing or not. The second is observed from the extent of which associations become more political, and whether new associations are emerging or not (Goldfrank 2007, 148).

Studies of the dynamics of local politics in the context of the decentralization have often revealed that the spread of power from the center to the periphery is actually a continuation of what had been established for 32 years under the New Order (See Hadiz 2010), and decentralization is a new platform for them to return to power. This viewpoint tends to disregard the dynamics of civil society, imagining them to be constantly remaining under the hegemony of the ruling class, and lacking the room to negotiate. Contrary to that view, this paper will put itself in the context of changes of decentralized power, and observe how groups that have long been repressed by the regime, now come out, speak out, and demand their rights, even though the state remains controlled by local elites. The efforts of marginalized communities is made possible by to the implementation of the decentralization of power, which coincided with the installation of formal democracy, all of which have changed power relations and relations of state and civil society.

In particular, this paper examines how social classes created by unequal agrarian structure actualize themselves, and the way that they exploit the opportunities provided by the new structure of electoral democracy. Thus this study examines the relationship between the control of local agrarian resources and the power structures formed, which determine the nature and dynamics of local actors of democracy. This paper will be guided by three interrelated key questions: How does the unequal agrarian structure formation occur? What are its implications for the formation of social classes? What are the steps taken by social classes based on agrarian control to articulate their respective interests in the context of decentralization of power? The three questions guide the process of explaining the dynamics of the depth of local democracy, in the sense of how the agrarian structure becomes an important basis for the return of local elites to control the state, and give rise to civil society movements that utilize political arenas and policies in the arena of decentralization through which fight for their rights.

The effectiveness of decentralization as a form of state presence at the local level is influenced by the quality of the local democracy, and local democracy also depends on the dynamics of the social classes that make use of this opportunity (Moore 1966). The strategy used in this research is to analyze the history of the formation of the agrarian structure in plantations, in both macro and micro levels. Furthermore, it observes the dynamics of political actors or social classes created by the history of the formation of the agrarian structure in the local democratic arena. This analysis becomes the starting point to observe how decentralization spawned political arenas and policies that enable marginalized groups to obtain 
their rights. Also observed is the gap in the changing power relations of the decentralization era, which allows peasants to succeed in their movements. Interviews were conducted with peasant organizers, regency and village government officials, and involved discussions with peasant advocacy groups, and supported by the study of relevant documents.

The study found that during the era of decentralization of power and local democracy, the state returns under the domination of those who benefit from the history of agrarian structure formation since the colonial era to the New Order, which in the context of Blitar are the ones associated with estates. However, in the same period, marginal groups, namely peasants, are also able to capitalize on these opportunities to seize their rights. This is evidenced by the success of peasants in suing estates and demanding redistribution of lands for farming. The condition is apparently closely related to the following: first, the history of the formation of the agrarian structure, which has not changed since the colonial period, second, decentralization and installation of local democracy altering the relationship of social classes formed from the agrarian structure; third, fragmentation among plantation owners from the military, private sector, and cronies in the local bureaucracy, preventing them from controlling peasant movements; fourth, village elites who represent the state at the local level are also losing their control over the class of poor peasants or clients; they can only collaborate with the bourgeoisie such as business persons, although they tend to be collaborate in a pragmatic and transactional manner.

\section{Literature Review}

\section{The Interrelations Between Decentralization and Local Democracy}

Before going further it is important to distinguish local democracy from decentralization. They are two sides of the same coin, namely post-New Order development politics. Decentralization is often seen as a form of devolution of powers then held by the national capital, to regional centers at the regency/municipality level. Centralization of power during the New Order era is regarded to have alienated the community from the state, and decentralization is intended as a correction to that lapse.

In administrative terms, decentralization is considered to have the potential to create effectiveness and efficiency in the management of local affairs, especially the public service. This is possible because local governments know more about local problems, compared to the central government, and hence this could minimize procedures, which otherwise could become lengthy and complex. In economic terms, decentralization is seen to increase economic development and reduce poverty (Rahmatunisa 2011, 2-9). Because decentralization gives local communities power to monitor the political leaders of their choice, it can motivate governments to satisfy their constituents. In political terms, decentralization is considered to facilitate political stability and encourage participation. In particular, decentralization is more than a matter of delegating authority from the center to the regions; it is basically a form of local government expected to achieve 
administrative, economic and political goals. It also becomes an arena to bring closer communities to the state, and between citizens and the government.

The ways of making the local government, endowed with authority, able to bring people closer to the state, to make the public a part of policy, oversee public officials, choose local people who understand and care about the affairs of the local community, are all managed within an institution termed local democracy. Political liberalization as an important basis for democracy is a condition in which power is spread vertically and horizontally, characterized by a wide-open space for civil society organizations to express opinions; ensuring participation and expression (Lay 2012, 209). Such local democracy does not just stop at representative democracy, which celebrates elections of executives and legislative members in the local level, but far more importantly, refers to the democratic participation in which people are actually involved in decision-making (Landman 2009, 8). It seems that the second dimension of local democracy has often been unfulfilled, resulting in much disappointment because communities feel that their interests are not accommodated.

The effectiveness of decentralized governance is closely related to the depth of democracy, and conversely, decentralization could contribute to the deepening of democracy, if it expands the arena and opportunities for citizens to participate in public decision-making. Expanding the depth of democracy means including disadvantaged and vulnerable groups into public affairs. Expanding the arena refers to bringing political and social issues under the authority of the local government, and not leaving them to market mechanisms. In other words, democratic decentralization means redistribution of power (the authority to make decisions on the allocation of public resources), both vertical (involving people) and horizontal (expanding the area of collective decision-making) (Heller 2001 in Rahmatunisa 2011, 11). In the context of this research, decentralization is a form of response of the local authority to the collective action of peasants demanding redistribution of estate lands in Blitar, which then formed a team for dispute resolution and led to the decision of the regent to redistribute lands as demanded. The success of the peasants is not simply caused by the decentralization process, but is the end result of a long struggle for their rights, made possible by transparency in the system and open political opportunities.

While both decentralization and local democracy open the opportunity for everyone to get into public arenas, their dynamics are closely connected with the history of control of local resources. The wide-open space of political liberalization is exploited and treated differently by different groups in the community. In Blitar, the history of the agrarian structure affects how groups that have long controlled agrarian resources utilize the local democratic arena, and also how marginalized communities or peasants demand their rights of land.

The installation of local democratic institutions and procedures has at least created important changes that allow not only powerful groups to control resources, but also proletarian groups to do the same. As Lay (2012) mentioned, the installation of democratic system and institutions does not happen in a vacuum, but within the social composition and local political-economic conditions. Changes 
in power relations occur from the central level, down to the village level, even to hamlets. The national capital is no longer the sole center of power; power spreads out to the regions and spreading to the civil society down to the lowest level. Political parties, politicians, market and businesspersons, as well as groups of community organizations, continue to be important actors in the contestation for resources. This development coincided with the rise of power, not only of new civil society groups, but also of cultural communities whose structures are based on informal consensus. These groups have become an important part of any political processes at the local level, especially in the attempt to gain benefits from available political-economy arenas.

\section{Methods}

Much of the data in this research are collected through interviews. Interviews were conducted with no previous selection of subjects, but using the snowball technique. The first person interviewed was the section head (Kasi) of Land Stewardship in Blitar land office. The interview was to determine land use in Blitar, particularly in Modangan: the uses, the area, etc. Continuing the interview, further interviews continue with staff members handling land conflicts in Blitar to find locations and issues of land conflicts, parties of the conflict, causes, and the extent of the resolution, especially the solution to the conflict in Modangan. Overall, the number of people interviewed was about 18.

In addition to interviewing, several land documents in the land office are photocopied due to their importance. Important documents that are obtained include the History of Estates in Blitar book, which explains the history and latest condition of 22 estates in Blitar. A previous research report used in this research is the systematic research document of the National Land Institute team (STPN) on poverty reduction and restructuring of Blitar region in 2010. Another important study is the report by Dewi Kartika about the struggle of farmers in Kulonbambang, Blitar.

\section{Results and Discussion}

\section{Changes in Power Relations Between Agrarian Social Classes}

An agrarian structure is the condition in which a group of people controls vast areas of land, and on the other hand, a large number of people who lack control or own small areas of land, resulting in a stratification or hierarchy in terms of control or ownership of land (Sitorus and Wiradi 1999 in Iriani 2008, 8). A capitalist agrarian structure is one in which most of the land is occupied not by tenants, but by plantation estates, creating a hierarchical social class structure. The top of the structure is the major landowners, the center is wealthy farmers and, the bottom is peasants, non-landowning farmers (landless) and poor farmers. The character of the agrarian structure has been formed since the colonial period, and has not changed in the post-independence period. During the Old Order, state capitalism in the agrarian sector is a continuation and expansion of the colonial period. This 
condition becomes stronger in the New Order that put economic development through plantations as a key strategy of development.

The domination of estates, constricting farmlands for the surrounding population, and resulting in the rise of enclaves of poverty near the estates, is an agrarian structure that has been formed for a long period of time. The important question in the context of understanding the differences in the impact of the decentralization of power to marginalized groups is how the social structure formed by the history of the unchanging agrarian structure has happened. This will help us to see the efforts of each group in harnessing the momentum of the political opportunities offered by decentralization and local democratic practices.

Blitar is an area where the bottom layer of the agrarian structure is populated by landless peasants, and the layer above populated by farmers owning a small area of land, and still above it a small number of farmers possessing large areas of land. Yet the largest areas of land are controlled by the state, military, and private groups. The dominance of these groups does not occur all of a sudden, but formed by the history of the formation of agrarian structure in Java. At the local level, in Blitar, estate owners became the dominant group in the socio-political structure, and they make use of electoral politics to control the state. In other words, people who hold the titles to plantation estates in Blitar are also the same ones who are the local ruling elites.

In the colonial period, there are at least a number of agrarian policies instrumental in the creation of the social class structure in Java, namely the open door policy for capital inflow, modernization of the bureaucracy (Simbolon 1995; Lutfi 2011), the compulsory cultivation system (1830-1870), and the Agrarian Law of 1870. The open door policy brought foreign investment into the plantation sector, giving new authority status for native rulers, and gave rise to the process of proletarianization. The colonial state, local colonial officials, indigenous aristocrats and private entrepreneurs formed a coalition that strengthened state capitalism. This in turn gave rise to the proletariat, consisting of a varied group of plantation workers, farm laborers, or forced labor (Kartodirdjo and Suryo 1991). Down to the village level, this system strengthened the authority of the head of the village and officials, rural landowners, and the colonial government officials who obtained protection and benefits from this system. The estate system resulted in initial steps of the proletarianization process, by creating wage laborers working in plantations. These workers came from the group of landless peasants or small plot farmers who generally come from areas far from the plantation site.

In the early days of the Indonesian republic, the configuration of power long established in the colonial period did not change much. The role of the colonial state ended, and Dutch administrative personnel left Indonesia, but in that era, private entrepreneurs, including those in the plantation sector, continued to runs their activities before the nationalization of foreign companies was enacted. Native rulers, who previously benefited from the colonial system, came in and become part of the new state. They are also indulged by the "Benteng Program", which gives licenses to local entrepreneurs to obtain facilities, yet this was ineffective as most of them did not have the ability to manage large-scale plantations, like 
businessmen from Chinese descent. On the other hand, the lower classes of Indonesian society gained a new momentum to seize what they perceive to be their rights. Their actions are facilitated by various political parties bent on a mission to struggle for the lower classes. During the early days of Indonesian independence, these parties spearheaded nationalization of foreign companies, although they were eventually abandoned (Kanumoyoso 2001). At the top level, native rulers consolidated themselves through control of important sectors including plantations, and similarly consolidation at the lower level was driven by political parties, especially the Indonesian Communist Party (PKI).

In the plantation sector there are at least three important forces involved: those who became part of the state and thus given the authority to manage plantations controlled by the state following nationalization, but not of the military; the military itself, which took over many plantations; and proletarian peasants mobilized by the Indonesian Communist Party to control important sectors of the state, especially plantations. How these forces were configured in the early republican era and reproduced themselves in subsequent periods is strongly associated with the issue of initial plans of Indonesia's economic development, the Round Table Conference (KMB), the struggle for West Irian, attitude toward foreign capital, and the nationalization of foreign companies (Kanumoyoso 2001). It can be said that during the old Order, plantations were controlled by the state, and was the inception of state-owned enterprises, while others were controlled by the military, and at the same time political parties continued to build the strength to release the grip of foreign companies and legacies of the colonial era. At this time, grassroots groups actually gained momentum to consolidate, and each had political channels with the facilitation provided by political parties to these groups. But they faced a stronger force, namely the military and its cronies, who had earlier controlled important corporate sectors especially plantation estates.

With the collapse of the Old Order in the 1960s, the subsequent New Order immediately stabilized state capitalism through liberalization of capital and expansion of estates. Associated with the management of agrarian resources, Kasim and Suhendar (1997, 97-108) classified the New Order era into a number of periods. The first was the exploitation of natural resources (1967-1974) performed by issuing the Law on Foreign Investment (UUPMA 1967) and the Law on Domestic Investment (UUPMDN 1968). The second period was "productivity without structure organizing" (1974-1983). The main program in this period was the implementation of a green revolution. Behind this policy, there was an intention to create political stability through creating food security, especially for urban inhabitants, providing rural employment, and embracing large landowners. The third period was deregulation and commodification of land (1983-1990). The government prepares regulations to provide land to capital owners through the Minister of Domestic Affairs Regulation No. 12/1984 on the Procedures for Granting Lands and Rights to Land, intended primarily for investors in accordance to UUPMA of 1967 and UUPMDN of 1968.

Restructuring of political parties and keeping society away from politics are strategies to maintain military rule, state bureaucracy, plantation owners who are 
cronies of the military and the state. The measures to depoliticize the society were carried out systematically (Fauzi 1997, 120-124). First, transmigration substituted land reform, transforming it into a technical problem. Transmigration was assessed to slow the buildup of landless classes in rural Java, which was considered a source of political movements. Second, participation of farmer organizations in agricultural programs was eliminated, and HKTI was recognized as the sole official farmer organization. Third, implementing the policy of floating mass on the eve of the 1971 elections, cutting the ties between the rural population and political parties. Fourth, the Rural Governance Law was issued in 1979, which made villages lost their dynamic democratic political processes. Fifth, violence apparatus such as the police and military were involved in the monitoring of political dynamics and rural development.

Actually, during the New Order period there was an available opportunity in which the middle class (petty bourgeoisie) and the wealthy perform class consolidation without being bothered by non-existent opposition. The era also saw the establishment of capitalist classes that are not derived from the feudal class, but from the new middle class (Setiawan 1997, 200-203). The New Order was basically built by the rural middle classes and rich farmers, who have the opportunity and access to the bureaucracy and new business efforts. The absence of sharp differentiation between the rural classes led to the unification of the village elite into the new political elite. It is because of that class-consciousness was never formed (Utrecht 1976).

The post-New Order situation is characterized by political liberalization that provides a wide space for anyone to express himself and fight for his interests. The rural proletariat, petty bourgeoisie and the bourgeoisie are looking for a space that allows them to survive. Each one stands on their autonomous basis, and are not fully a part of similar groups elsewhere. As the rural proletariat do not have sufficient class consciousness and do not have clear political views (Utrecht 1976, 273), the movement seems to be fragmented. These movements are not related with similar movements from other farmer groups beyond the problems they are facing, and therefore these movements are always in need of prime movers from outside. During the Old Order, the driving force consisted of teachers and students (Utrecht 1976, 276-277), who are also involved in political parties; they had not experienced depoliticization. Meanwhile, in the post-New Order are, their role as driving forces has been taken over by NGOs and student activists who are often not members of political parties, even having an anti-political tendency. The relationships built with other groups are not strategic, but tactical instead, which ends when the goal has been attained.

The petty bourgeoisie or the middle class no longer has enough power in the face of the rural proletariat as they began to move. Their long-time integration into the state, even at the lowest levels of the bureaucracy, has prevented them from easily merging with the proletariat. This is why in many movements of the proletariat, there is no involvement of village officials, village heads and other village elites. This petty bourgeoisie feels safer to merge with the state and collaborate with the big bourgeoisie, who managed to integrate themselves back 
into the state through political liberalization and bureaucratic modernization in the decentralized era.

The big bourgeoisie is the group able to take the greatest advantage of the situation of political liberalization. The group is integrated back into the state through democratic mechanisms. The high political costs required by new mechanisms of electoral democracy can only be fulfilled by the big bourgeoisie. Collaboration with the small bourgeoisie is still considered to be important and beneficial, because each party earns rewards from the collaboration. Yet communication with the proletariat continues to be done by building populist rhetoric. All this were done to establish their political position in the state arena, while continuing to dominate other important sectors of the economy.

\section{Schematic 1. Relations of Agrarian Social Classes in the Era of Political Liberalization and Decentralization}

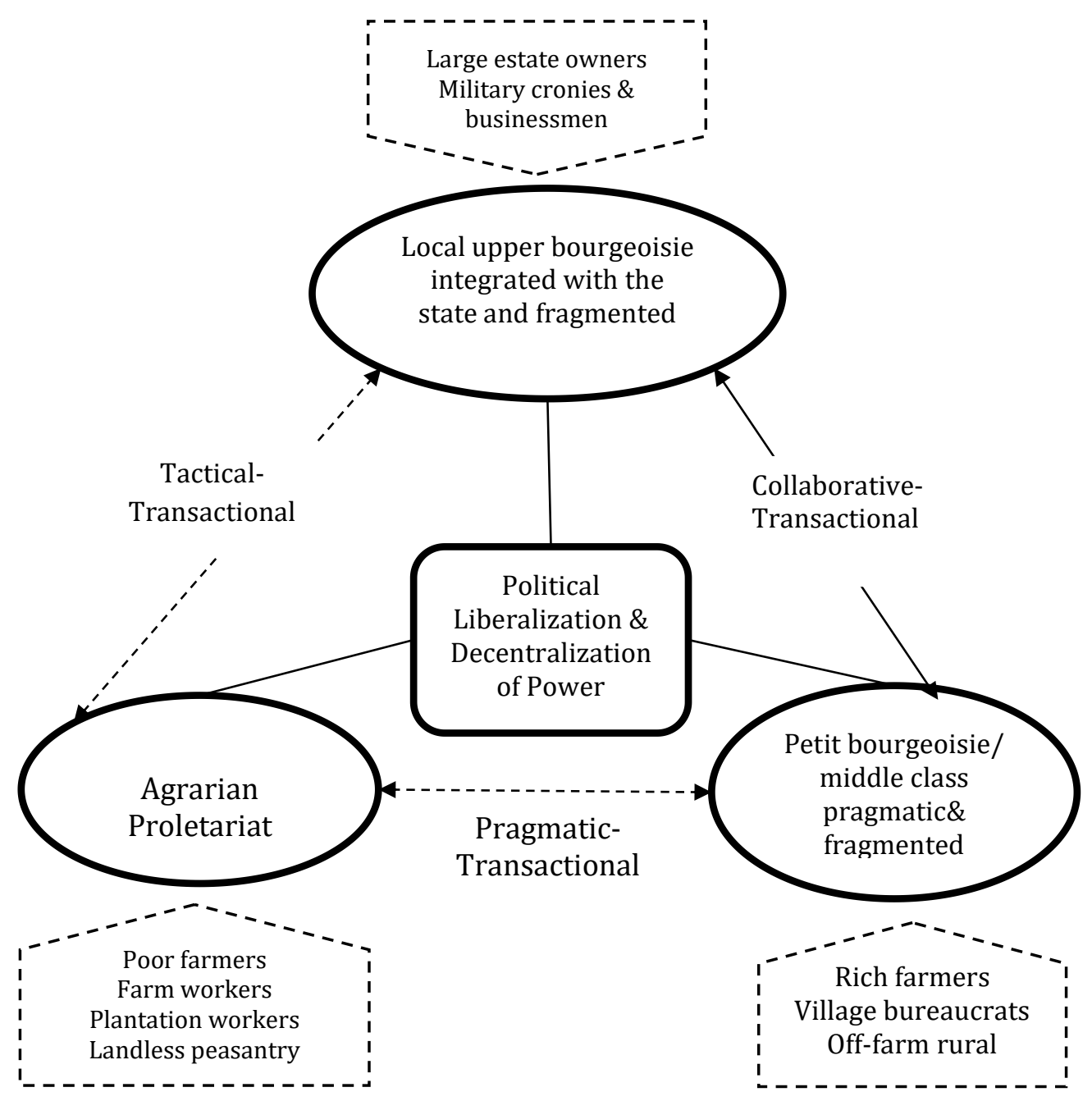


In a time of decentralization, the changing power relation between the bourgeoisie and the petty bourgeoisie becomes a gap used by the proletariat to seize their rights. The bourgeoisie, despite the opportunity to take control of the state through high cost politics, suffer from internal fragmentation in pursuing their own interests and winning dominance. The middle class, or petty bourgeoisie, is very pragmatic, losing their dominance of the rural proletariat who no longer maintain a patron-client relationship. This group finds it easier to collaborate with the bourgeoisie, than to support the struggle of a group of landless peasants. The following section will describe the dynamics between these classes in the context of decentralization.

\section{The Return of Local Elite Domination in the Arena of Decentralization}

The changing situation becomes highly attractive to local elites. They went en masse into the available political spaces to gain power and other benefits. It is not only the local executive elite who is a plantation entrepreneur who goes into politics, but also other figures in the local parliament. Although it is very difficult to obtain comprehensive data on how many plantation officials become MPs, activists and local residents know that they have also become important figures in the political parties. In short, many local political party official positions are held by people who have more economic resource support. This is possible, because in fact the procedures of local democracy are designed to return them to the dominant position.

Collaboration with the rural small bourgeoisie, namely the village chief and his officials, remains a method to preserve dominance. The success of the candidate pairs in the 2010 local elections was not only due to the support and funding of political parties that are strong at the regency level, but most fundamentally was caused from the support of the village elites. The kamituwo or heads of hamlets, while not having significant power and influence, remain as role models in villages. They are usually not burdened with complicated affairs, but are available every day to meet and interact with villagers. The incentive politics applied by the regent in the previous five years proved to be very effective in gaining support from the vast majority of these kamituwo. Unlike in the past where kamituwo really pandered to the village head, in the present, kamituwo do not always agree with the village head, except in technical and instructional matters.

Other village elites are associated with the state, but are elected directly by the citizens, being in a unique situation, i.e. having a full legitimacy from the grassroots as they are directly elected, while on the other hand they have a clear instructional relationships with the state bureaucrats at the upper level. The competitive local political processes force regency-level elites to establish strong relations with the village elites. In such a position, village elites such as headmen have a strong bargaining position when dealing with regency elites who control funding sources from the state. The crucial and instrumental position results in the creation of many village head forums, which can then be used as a vehicle to gain any interests. Such forums are in fact replicas of the formal organizational hierarchies in the government. However, communications in the forum are less formal, and the 
forum provides a space allowing discussion of issues that cannot be discussed in formal situations.

While the relationship between the village head and villagers does not have a high intensity in the patron-client nature of the relationship as it was in the past, the position of the village head remains influential at the village level. Meanwhile, the village head cannot always satisfy the wishes of all, or even a group of the villagers, because he is bound by certain conditions in which the state provides instructions and demands coordination. This is a reason why in several villages that are experiencing agrarian conflicts, the position and role of the village head tend to be indecisive, instead of being firmly supporting the villagers' demands. In other cases related to investment, village heads tend to favor the plans of entrepreneurs and local elites in the regency level.

\section{Peasant Negotiating Spaces: From Confrontation to Collaboration}

Although the bourgeoisie have regained power at the local level, it does not mean that there are no opportunities created allowing peasants to obtain land rights. Some of the policies issued in the decentralization era that are associated with farmers in Blitar include the National Agrarian Reform Program (PPAN) and creation of the Land Dispute Resolution Facilitation Team (TFPSP). The team was established in 2001, and has the role of bringing disputing parties to reach settlement of land disputes. The role TFPSP is also to prevent horizontal conflict in the community. PPAN is a program to award land certificates to farmers who do not have them yet. In 2007, through this program, BPN publishes 10,654 land rights certificates to people from nine villages, namely Ngaringan, Gadungan, Sumberagung, Sumberurip, Kalimanis, Resapombo, Bumirejo, Sidomulyo and Balerejo. Yet there is still much disputed land that cannot be resolved by such certification program (Tempo.co 2008).

The role of TFPSP is considered to be less than optimal, due to a number of reasons. First, there are many agencies, bodies, and elements of government entities that are involved, making it difficult to coordinate team members, and each time it holds a meeting, a different representative will come from its member agencies. Second, as TFPSP consists of officials holding certain positions in the government, when they are transferred, the land dispute resolution process becomes disconnected. Such a process of settlement should be done by the same persons from the beginning until the end, and disconnection will only make the process ineffective. Third, there is a lack of political support from the regional parliament of Blitar, which also resulted in the fourth problem, namely lack of budget, making TFPSP unable to resolve disputes involving 28 locations involving more than ten thousand households (sitasdesablitar 2012).

Such stagnation results in many local farmers organizations take other paths to fight for their rights, either through litigation as used by farmers' groups in Karangnongko, or through a long series of non-litigation actions. Besides, local farmers organizations joined together in an umbrella association called Blitar Aryo Farmers Association. The non-litigation method is preferred by the farmer groups, because using this method, they are not easily co-opted by forms of legal 
bureaucratization. Of the many farmers organizations, only one has managed to win in the state court, up to the Supreme Judiciary level, and even then they were facing administration of justice issues and BPN was unable to immediately start land redistribution.

The Karangnongko farmer group in Modangan chose the legal pathway in the face of bureaucratic stagnation of land rights administration. The residents in this village are split in two, one side choosing the path of collaboration with the bureaucracy and not taking legal action; and the other party does not believe in collaboration and choosing the legal route. The path of collaboration with the bureaucracy is done by applying for a request of land redistribution of the Karangnongko estate to the National Land Agency (BPN). It was expected that through BPN's authority and proven programs such as PPAN, it would soon deal with the issue of redistribution to the central level. This pathway involved the village bureaucrats to expedite the request. However, the other group does not believe in this method, seeing that lawsuits filed to the court turn out in victory. Mass mobilization was used to suppress the defendant and to win their lawsuit in court. In addition to the litigation path, mass rallies were also done in support of their cause. While the Supreme Court, through the Blitar court, has ordered the execution, it cannot be done in a convincing manner. This was primarily caused by lack of support, and lack of compromise between the applicants and the plaintiffs, and lack of a common vision between BPN and the plaintiff. As a result, the execution cannot be done properly. Although the plaintiffs have won the dispute de jure, the land tenure remained unchanged de facto, and even plots obviously farmed by farmers cannot be certified, as BPN is reluctant to do so.

From another location, there is another story of struggle. The farmer group in Kulonbambang, Gambaranyar, took different paths beginning with confrontation and ending in collaboration that eventually forced local elites to grant their demands. After the founding of Pawartaku, a union of farmers in Kulonbambang, land occupation, which has been begun earlier, becomes more widespread. Members of Pawartaku began occupying areas (especially neglected land and land located in well-hidden locations) to be planted and cultivated. This action was initially performed clandestinely. In the early days of the struggle for the occupation of land, most participants continued to work as laborers, while some of them have decided to quit their previous occupations and join the struggle in full. Villagers who remain working in the plantations played a role in relaying information related to the estate. Gradually, the occupation movement was performed in the open after more lands were occupied (Kartika 2011).

In 2000 the movement came out by taking action to the regional parliament and succeeded in forcing them to issue a commitment to resolve the dispute. At that time, in the regency the Land Dispute Resolution Facilitation Team (TFPSP) has been established, facilitated by the parliament. From this meeting, emerged an agreement between the people and the TFPSP, that the people will accept a decision to receive 255 hectares of the 500 hectares they already control, and restore control of the remaining 245 hectares to the state for the repayment of the corporate's debts. In early August 2001, there was a recommendation from the 
chairman of the Blitar regional parliament to meet the demands of redistributing lands already occupied from Kulonbambang estate, with an area of 255 hectares. On 7 March 2002, in a meeting between the residents and the Blitar Land Office, bank, regional parliament, regent and vice regent of Blitar, KP2NL Malang (KPKNL Malang), an agreement was reached, approving redistribution of 255 hectares of 955.5 ha of land in the location of Kulonbambang estate. A month later, in early April 2002, the regent of Blitar sent a recommendation letter to the national office of the BPN to immediately set the 255 ha from Kulonbambang as an object of redistribution. This was done on 13 May 2003 (Kartika 2011).

Both cases above illustrate different paths taken by each local farmer organization in the fight for their rights. One important lesson is that none of them chose to pursue the fight through political parties. In addition to changes in the power relations between agrarian social classes, another opportunity is offered by national policies favoring farmers such as Tap MPR IX/2001 on Agrarian Reform and Management of Natural Resources. In 2007, the National Land Agency (BPN) issued the National Agrarian Reform Program (known as PPAN). In the year 2009, it also introduced a land certification program (known as Larasita). Subsequently, in 2010, the government issued Government Regulation No. 11/2010 on Control and Utilization of Uncultivated Lands, making use of unutilized land for distribution to the public. Although these programs are very important in opening the door for the struggle of the farmers, but the role of the peasant movement itself remains very decisive.

\section{Conclusion}

In the post-New Order era, the most prominent political change in Indonesia is the implementation of two reforms in the administration of authority, namely decentralization and local democracy. Decentralization is intended to create a system of regional management that is in accordance with the aspirations of the inhabitants, while local democracy is a mechanism regulating how powers in one region gain legitimacy and capability of running local government in a more democratic manner. In practice, both decentralization and local democracy are closely related, and in fact the quality of decentralized management is strongly influenced by the quality and depth of local democracy. Pathologies of decentralization, such as corruption co-optation of resources by local elites, are allegedly the result of the liberal implementation of local democracy. This conclusion is supported by many empirical studies that argued about the hijacking of local democracy by local elites for their interests through populist and democratic rhetoric.

Decentralization and political liberalization down to the local level are also needed by marginalized elements of society to seize the resources that they are rightfully entitled. This study shows how farmers in Blitar benefits from opportunities provided by decentralization and local political openness to claim their rights to land that has long been dominated by plantations. But more interesting is that the whole struggle for democracy by the farmers did not utilize 
local democratic institutions, namely political parties. They have the realization that all political institutions of local democracy are mere playthings of local elites, and unable to bring forward the aspirations of the peasants. The extraparliamentary ways they took succeeded in forcing the parliament and the government to grant their demands. This suggests that political parties, as part of the liberal electoral democracy system is not rooted in the grassroots, and instead only facilitates lust of power for the local elites.

The dynamics of local democracy in the decentralized arena do not appear all of a sudden, but are the fruits of a long history of domination of the livelihoods of local communities. These conditions ultimately determine the structure of the dynamic struggles of the social classes in the arena of local democracy. In Blitar, the domination of agrarian resources by plantation estates has long been a result of a series of policies and agrarian politics since the colonial period to the end of the New Order, which was not in favor of the people's productivity and safety. Hence Blitar has a divided agrarian structure; on one hand, most lands are dominated by plantations, while the remaining lands are contested by the growing number of population. This structure proved to have failed in creating prosperity,and instead generated enclaves of poverty around the estate locations. During the decentralization, these plantation sites turn into conflict sites which spread and escalate.

The groups that take the greatest advantage of opportunities provided by political liberalization in the decentralization era are the classes formed from the long history of local agrarian structure. In colonial times, they were colonial bureaucrats, local authorities and planters;in the Old Order they were elements of the state (legacies of the colonial state bureaucracy), the military, political parties and planters-military cronies; in the New Order they were the military, the state bureaucracy, planters-military cronies. In the decentralization and local democracy era, this has not changed much: they are the elements of political parties, local-national businesspersons and top-level bureaucracy. Grassroots groups, namely plantation workers, agricultural laborers, landless peasants and poor farmers have different opportunities and self-actualization methods in each period. During the colonial and New Order periods, they suffer from the same condition, as they were co-opted by the elites, and deprived from political consciousness; if they were involved in politics, they had to voice the political views of the elites (Utrecht 1976). While in the Old Order, the condition was similar as it is in the decentralized era; during the Old Order era, there were grassroots movements led by political party activities, although ultimately not resulting in strong and coherent political consolidation of the proletariat, while in the decentralized era, such grassroots movements are not associated with political parties, and extra-parliamentary actions are preferred. Liberal local democracy is not the logical choice for marginalized groups to fight for themselves, inasmuch as it is used as political vehicles of local elites to seize power and establish their dominance.

The practices of decentralization and local democracy are not located in a vacuum, and insensitivity to local conditions can result in outcomes that are not 
only different, but also excluding towards the common people. It is evident that the system and procedure of local democracy, which have been applied in varied manners, have resulted in more tools for local elites to gain power. On the other hand, the system has never been used by the lower classes to gain their rights. To achieve an understanding of the diversity of the dynamics and outcomes of local democratic practices, this study suggests a route of analysis that does not separate the issues of local democracy from the history of resource control, social class formation and historical changes, and to study the arenas chosen by the proletariat in their struggle. An analysis of the quality of local democratic practices that are separated from the issue of welfare will consciously or not confirm the local oligarchy, as indicated by the very liberal practice of local democracy.[]

\section{References}

Fauzi, Noer. 1997. “Anatomi Politik Agraria Orde Baru." Dalam Tanah dan Pembangunan, edited by Noer Fauzi. Jakarta: Pustaka Sinar Harapan.

Goldfrank, Benjamin. 2007. "The Politics of Deepening Local Democracy: Decentralization, Party Institutionalization, and Participation." Comparative Politics 39, No. 2 (January): 147-168.

Hadiz, Vedi R. 2010. Localizing Power in Post-Authoritarian Indonesia: South East Asia Perspective. California: Stanford University Press.

Iriani, Artanti Yulaika. 2008. "Distribusi Kepemilikan Lahan Pertanian dan Sistem Tenurial di Desa-Kota (Kasus Desa Cibatok 1, Kecamatan Cibungbulang, Kabupaten Bogor, Propinsi Jawa Barat)". Unpublished thesis. Bogor: Institute Pertanian Bogor.

Kanumoyoso, Bondan. 2001. Menguatnya peran ekonomi negara nasionalisasi perusahaan-perusahaan Belanda di Indonesia, 1957-1959. Jakarta: Pustaka Sinar Harapan.

Kartika, Dewi. 2011. "Dari Orang Percil Menjadi Petani Merdeka: Perjuangan Agraria di Kulonbambang, Blitar.” Unpublished Research.

Kartodirjo, Sartono, dan Djoko Suryo. 1991. Sejarah Perkebunan di Indonesia; Kajian Sosial Ekonomi. Yogyakarta: Aditya Media.

Kasim, Ifdal dan Endang Suhendar. 1997. "Kebijakan Pertanahan Orde Baru Mengabaikan Keadilan Demi Pertumbuhan Ekonomi." Dalam Tanah dan Pembangunan, edited by Noer Fauzi. Jakarta: Pustaka Sinar Harapan.

Landman, Todd. 2009. Concepts Matter: Delineating Democracy, Governance and Human Rights. Sweden: International IDEA.

Lay, Cornelis. 2012. "Democratic Transition in Local Indonesia; An Overview of Ten Years Indonesia." Journal Ilmu Sosial dan Politik 15, no. 3 (Maret): 207-219. 
Luthfi, Ahmad Nashih. 2011. Melacak Sejarah Pemikiran Agraria: Sumbangan Pemikiran Mazhab Bogor. Bogor: Sajogyo Institute.

Midlarsky, Manus I. 1992. "The Origins of Democracy in Agrarian Society: Land Inequality and Political Rights." The Journal of Conflict Resolution 36, no. 3 : 454-477.

Moore, Barrington. 1966. Social Origins of Dictatorship and Democracy: Lord and Peasant in the Making of the Modern World. Boston: Beacon Press.

Rahmatunisa, Mudiyati. 2011. "Desentralisasi dan Demokrasi." Governance: Jurnal Ilmu Pemerintahan 1, no. 2: 1-21.

Setiawan, Bonnie. 1997. "Perubahan Strategi Agraria: Kapitalisme, Agraria, dan Pembaruan Agraria di Indonesia." Dalam Tanah dan Pembangunan, edited by Noer Fauzi. Jakarta: Pustaka Sinar Harapan.

Simbolon, Parakitri T. 1995. “Menjadi Indonesia.” Jakarta, Kompas.

Sitasdesablitar. 2012. "Ketidakadilan adalah Sebab, Sengketa Agraria adalah Akibat." sitasdesablitar.wordpress.com, $22 \quad$ Juli 2012. https://sitasdesablitar.wordpress.com/2012/07/22/ketidakadilan-adalahsebab-sengketa-agraria-adalah-akibat-3/.

Sorj, Bernardo dan Marjorie Hutton. 1980. "Agrarian Structure and Politics in Present Day Brazil." LatinAmerican Perspectives 7, No. 1: 23-34.

Tempo.co. 2008. "Warga Blitar Banyak Belum Terima Sertifikat Agraria." Tempo.co, 10 Maret 2008. https://nasional.tempo.co/read/118900/warga-blitarbanyak-belum-terima-sertifikat-agraria.

Utrecht, Ernst. 1976. "Political mobilisations of peasants in Indonesia." Journal of Contemporary Asia 6 (3): 269-288.

\section{Author Biography}

Amin Tohari is the founder of the SatuKata Research School. He completed his PhD in The Department of Politics and Governance, Universitas Gadjah Mada, Indonesia. His research topic focus on critical agrarian research, political discourse, governance, and radical democracy.

Email: amintohari@mail.ugm.ac.id 